\title{
The Epic Cycle and the Ancient Novel
}

\section{Citation}

Elmer, David F. 2015. The Epic Cycle and the Ancient Novel. In The Greek Epic Cycle and Its Ancient Reception: A Companion, eds. M. Fantuzzi and C. Tsagalis: 596-603. Cambridge: Cambridge University Press.

\section{Published Version}

http://www.cambridge.org/catalogue/catalogue.asp?isbn=1316308359

\section{Permanent link}

http://nrs.harvard.edu/urn-3:HUL.InstRepos:30803005

\section{Terms of Use}

This article was downloaded from Harvard University's DASH repository, and is made available under the terms and conditions applicable to Open Access Policy Articles, as set forth at http:// nrs.harvard.edu/urn-3:HUL.InstRepos:dash.current.terms-of-use\#OAP

\section{Share Your Story}

The Harvard community has made this article openly available.

Please share how this access benefits you. Submit a story.

Accessibility 
The Epic Cycle and the Ancient Novel

David F. Elmer

The "ancient novel" is a diffuse phenomenon, comprising a core of clearly fictional texts generally acknowledged (by classicists, at least) as meeting the criteria for designation as "novels," and a "fringe' of prose texts that flirt with fictionality to varying degrees. ${ }^{1}$ If, for the purposes of this brief discussion, we restrict our gaze to the seven extant texts typically assigned to the core - the five Greek romances (Chariton's Chaereas and Callirhoe, Xenophon's Ephesiaca, Achilles Tatius' Leucippe and Cleitophon, Longus' Daphnis and Chloe, Heliodorus' Aethiopica) and the two "comic" novels in Latin (Petronius' Satyrica, Apuleius' Metamorphoses) — we will find that, in spite of certain promising convergences, it is not easy to identify direct connections between the Epic Cycle and this corpus. ${ }^{2}$ Obvious references to the content of the Cycle are relatively infrequent, ${ }^{3}$ while arguably the most prominent display of Cyclic themes in the novels, the Sack of Troy recited by Petronius' Eumolpus, is, first and foremost, a parodic reworking of Roman texts (Vergil and Seneca), and only residually (if at all) an evocation of Greek models. ${ }^{4}$ The difficulty, to be sure, is compounded by the very fragmentary state of our evidence for the Cycle itself, which makes it virtually impossible to say whether any given reference to the stories reported in the Cycle is intended as an allusion to a specific Cyclic text, or instead draws merely on general knowledge of heroic legend. All the same, the Cycle makes a disappointing showing in the extant novelsespecially considering the many good reasons for supposing that traces of its influence might be there to be found.

There is, first of all, the suggestive chronological proximity of literary trends. The mid- to late- $1^{\text {st }}$ century CE is a period that sees not only the birth of the Greek romance (so far as we can tell), but also a renewed interest in the penumbra of Trojan legends surrounding the Homeric poems. Much uncertainty surrounds the dating of the novels, but there is now broad consensus that Chaereas and Callirhoe, the earliest of the extant Greek texts, should be placed roughly around $50 \mathrm{CE}$, and there is a strong likelihood that the earliest fragmentary romances (the so-called Ninus and Metiochus and Parthenope) were composed in the decades immediately thereafter. ${ }^{5}$ Meanwhile, Petronius' Sack of Troy is only one indicator of a noticeably more intense engagement in the same period with the more obscure details of Trojan legend. ${ }^{6}$ Others include the Trojan Oration of Dio of Prusa, the Trojan war trivia collected in Ptolemaeus Chennos' New (or Novel) History, Statius' Achilleid, and possibly Lucan's Iliaca (of which only two certain fragments remain). This interest is sustained into the second and third centuries, when it develops a distinctly novelistic cast: witness the Greek texts translated into Latin as the Diary of the Trojan War, pseudepigraphically attributed to a certain Dictys of Crete, and the History of the Fall of Troy supposedly by the Trojan priest Dares, as well as Philostratus' On Heroes. ${ }^{7}$ Works such as these speak to the fundamental amenability of Trojan (and thus Cyclic) themes to treatment according to the narrative predilections of imperial prose fiction. There is no obvious reason to discount the possibility that firstcentury experimenters with the form would not likewise have perceived the potential inherent in the Cycle.

Indeed, the extant novels - especially the five Greek romances - are far from reluctant to exploit epic models. All of them engage, sometimes directly, sometimes 
indirectly, with the Greek epic tradition. Chariton's Chaereas and Callirhoe illustrates the range of possibilities in this regard. After the marriage of the protagonists, the story's complicating action is set in motion by the plotting of Callirhoe's frustrated suitors, who are angered by the fact that Chaereas has succeeded where they have failed. The malicious suitors, their conspiratorial meeting to hatch a fatal scheme (1.2), even the contemptuous terms in which they characterize their rival, whom they describe as a peness "beggar" (1.2.3), all plainly evoke the Odyssey. At the same time, the destabilizing force they represent, the force that sets the plot in motion, is equated by explicit allusion with the event that sets in motion the entire Trojan saga: 'Such was the wedding of Thetis on Pelion, according to the poets' hymns; but on this occasion, too, a certain envious power was present, as they say Strife was then' (1.1.16). This might be counted as a rare example of allusion to one of the poems of the Cycle (the Kypria); more likely it is simply a reference to the more amorphous body of Trojan legend. There can be no doubt, however, about Chariton's many quotations from the Homeric poems, taken in roughly equal measure from the Iliad and the Odyssey. ${ }^{8}$

The whole of the epic tradition thus lies within the novel's reach. Without a doubt, Chariton is especially eager to situate his text in relation to epic models: the range and frequency of his epic references are exceptional. Nevertheless, all of the extant Greek erotic novels can be seen to engage more or less substantially with the master text for the romance of return, the Odyssey: 'To greater or lesser degree, and with varying degrees of specificity, all the novels are descants on the second Homeric epic. ${ }^{9}$ The Odyssey is a principal intertext for the novels of Petronius and Apuleius as well. Encolpius' wanderings and apparent persecution by Priapus, for instance, are commonly understood as comic transformations of the suffering imposed on Odysseus by a wrathful Poseidon, while the central scene of the Metamorphoses - the episode in the robbers' cave, which frames the Cupid and Psyche novella - simultaneously evokes both Odysseus' encounter with the Cyclops and his vanquishing of the suitors on Ithaca. ${ }^{10}$ The prominence of the Odyssey as a point of reference can be explained by the fact that it provides such a rich matrix of novelistic preoccupations and techniques. The narrative of return outlines a basic trajectory and a closural paradigm that are as relevant to Lucius' struggle to recover his human form as they are to the more literal homecomings of the Greek romances; Odysseus' dalliances and his longing for Penelope establish the utility of eros as a motive force for both 'centripetal' and 'centrifugal' modes of narrativity ${ }^{11}$; the episodic structure, particularly of Odysseus' apologoi, offers a model for the composition of an extended, self-renewing plot; the insertion of Odysseus' first-person perspective in a third-person frame exposes the contrasting possibilities represented by homodiegetic, heterodiegetic, and embedded narrators; and, finally, the contrast between the plausibility of Odysseus' 'Cretan lies' and the fantastic quality of his apparently truthful tales in Alcinous' palace signals an interest in exploring the very nature of fictionality. ${ }^{12}$

The Odyssey's preeminent position as a point of reference for the novelists is, therefore, guaranteed by its particular combination of formal and thematic properties. But many of the poems of the Cycle would appear to have equal claims in these regards. Aristotle famously contrasts the Cypria and the Little Iliad with the Iliad and Odyssey precisely on the basis of the episodic character of the former (Poetics 1459a30-b7).$^{13}$ So, for instance, the compositional structure of Xenophon's Ephesiaca, with its lengthy concatenation of discrete episodes exhibiting minimal causal links, bears a stronger 
resemblance to the Cypria, so far as we can tell, than to the Odyssey-although the Odyssey itself is more "Cyclic" in this regard than the Iliad. ${ }^{14}$ With respect to themes, Rohde already identified the Cycle as a potential source for the kinds of erotic narratives that would later exert an influence on the novel (in his view, through the intermediary of Hellenistic poetry). ${ }^{15}$ These seem to have been especially prominent in the Cypria, a poem that may have derived its name from the prominent role played by Aphrodite in the direction of the action $^{16}$ : in addition to the love affair of Helen and Paris - a story that may lie somewhere in the background of Xenophon's tale of Aigialeus, whose love affair with Thelxinoe resulted in their precipitous flight from Sparta (Eph. 5.1.4-11) - that poem also included a series of inset erotic tales narrated by Nestor (Cyp. Arg. 27-29 Bernabé) and several romantic episodes featuring Achilles (the affair with Deidameia, the ruse of marriage with Iphigenia, and the encounter with Helen, engineered in part by Aphrodite). Erotic motifs can also be traced in the Aithiopis, ${ }^{17}$ possibly in the Iliou Persis ${ }^{18}$ and in the Telegony, which recounted Odysseus' marriage with the Thesprotian princess Kallidike and brought the Trojan cycle as a whole to a conclusion with a convenient set of marriages. This happy ending through marriage even prompted Albert Severyns to declare that the Telegony 'marks the end of the epic genre, and announces a new genre, that of the prose romance'. ${ }^{19}$ Another staple of the novel, travel in foreign lands, was presumably much in evidence in the Nostoi, which featured, in the course of recounting the journeys of numerous heroes, an account of the time spent in Egypt by the reunited lovers Helen and Menelaus. ${ }^{20}$ Egypt, of course, is the novelistic setting par excellence. $^{21}$

This rich store of material, as noted above, has left few verifiable traces in the novelistic corpus. But the Nostoi and especially the Telegony, by virtue of their position as collateral narratives that circulated beside and contextualized the master-romance of the Odyssey, point to a form of indirect influence that the Cycle may have exerted on at least some novels.

One of the most distinctive features of the core group of ancient novels, which differentiates them from the bulk of ancient literature, is their avoidance of any direct reliance on external frames of reference - historical facts or literary traditions - to provide contextual support for their narratives. (Chariton-exceptionally, but perhaps not insignificantly, as we shall see-does construct certain links between his narrative and the history of Syracuse.) This autonomy vis-à-vis other narratives is in fact constitutive of fiction (and ancient fiction) as such. ${ }^{22}$ The difference from the Odyssey could not be more extreme: that text binds itself particularly closely to the contextualizing narrative represented by the Cycle. ${ }^{23}$ The tales of Nestor and Menelaos in Books 3 and 4 introduce embedded versions of the Nostoi, implying that the story of Odysseus' return is only the latest episode in a sequential narrative that begins well outside the limits of the poem. And Teiresias' prophecy, recapitulated by Odysseus in Book 23 (248-84), emphasizes that Odysseus' story will not conclude with the end of the poem, but will extend beyond-into the events narrated in the Telegony. The Odyssey, then-perhaps even more than the Iliad, which has its own set of internal connections to the surrounding Cyclic narratives - draws attention to its position within a larger narrative continuum, in a way that would seem precluded by the fundamental autonomy of the novels.

Two of the Greek romancers, however, strive deliberately to create the impression that the stories of their fictional protagonists escape the limits of their texts. It is tempting 
to think that they do so in part because their archetype, the Odyssey, suggested to them the desirability of introducing a "centrifugal" counterpoint to their "centripetal" acts of closure, and that they look to the Telegony, Severyns' 'romance' in verse, as a means of conjuring an extension of a story world that is, by its nature, strictly bounded by a single narrative.

The problems presented by the conclusion of Achilles Tatius' novel are wellknown. ${ }^{24}$ At the beginning of the text, the anonymous narrator encounters in Sidon a solitary Cleitophon, whose narrative of his adventures constitutes the rest of the novel; but Cleitophon concludes his story by telling only of his return with Leucippe to Tyre, and their intention to travel to Byzantium in the spring. The unclosed frame leaves open the question of what Cleitophon is doing (by himself!) in Sidon. Is it too much to see in

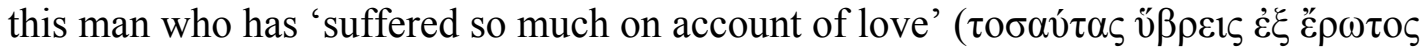
$\pi \alpha \theta \omega ́ v, 1.2 .1)$ and is now wandering apart from his beloved-a man, moreover, who will soon distinguish himself as an artful (and unreliable) narrator of his sufferings - an image of the Odysseus of the Telegony?

More suggestive still is the sequel predicted in Chariton's romance. At the novel's end, Callirhoe has returned to Syracuse with her first husband Chaereas, but she has left their son (whom Chaereas has never seen) in Miletus, in the care of her second husband Dionysius, who believes the child to be his own. Callirhoe, who compares herself to Odysseus early on (2.5.11), shares with her predecessor a multiplicity of conjugal ties, and she scripts for her unconventional family an eventual reunion that recalls the one that brings together Odysseus' nearest and dearest in the last poem of the Cycle. Callirhoe directs Dionysius to send her son to Syracuse after marrying him to his own daughter, so that he may be reunited with his maternal grandfather - and of course with his father, although she cannot mention this to Dionysius (8.4.6). This reunion is presumably to be happier than the one reported in the Telegony, in which Telegonus mistakenly killed his father, but it is similarly accompanied by the fusion, through marriage, of the distinct branches of the family.

Perhaps, however, the darker undertones of this Cyclic intertext ought not to be so quickly discounted in the complex interplay Chariton sets up between his fiction, its literary models, and history. Several scholars have suggested that Callirhoe's child, left in the care of Dionysius (whose name he might reasonably inherit) - a strange and apparently unnecessary anti-closural detail — is meant to be the tyrant Dionysius I, who succeeded Hermocrates (Callirhoe's father in Chariton's fictional world) as ruler of Syracuse. $^{25}$ This historical Dionysius in fact married a daughter of Hermocrates, who suffered greatly as a result of the union - according to Plutarch, eventually taking her own life (Dio 3). Chariton has clearly tried to connect his tale with Syracusan history, but here a seemingly irremediable discrepancy arises - is Callirhoe to be understood as the mother or as the wife of Dionysius I? Or somehow as both? The discrepancy is, if not resolved, at least reduced on a "Telegonic" reading of Chariton's blend of fiction and history, for the Telegony authorizes both roles: in a composite view that blends all the literary and historical sources, Callirhoe may be understood as a Penelope figure (the woman who marries the returning child) or / and as an Odysseus figure (the parent who suffers on account of the child). The last of the Trojan epics charts a possible interchange between the worlds of fiction and history; and the Epic Cycle, as a narrative that both 
inhabits and escapes the Homeric master-text, provides a vehicle by which the novel may transcend the limits of its own fiction.

\section{Works Cited}

Biraud, M. (1985) 'L"hypotexte homérique et les rôles amoureux de Callirhoé dans le roman de Chariton', in Sémiologie de l'amour dans les civilisations méditerranéennes, ed. A. Goursonnet. Paris: 21-7.

Bowie, E. (2002) 'The Chronology of the Earlier Greek Novels Since B. E. Perry: Revisions and Precisions', Ancient Narrative 2: 47-63.

Brioso Sánchez, M. (1992) 'Egipto en la novela griega antigua', Habis 23: 197-215.

Connors, C. (2002) 'Chariton's Syracuse and Its Histories of Empire', in Space in the Ancient Novel, eds. M. Paschalis \& S. Frangoulidis. Groningen: 12-26.

Davies, M. (1989) The Epic Cycle. Bristol.

Elmer, D. F. (2008) 'Heliodoros's "Sources": Intertextuality, Paternity, and the Nile River in the Aithiopika', Transactions of the American Philological Association 138(2): 411-50.

Förster, R. (1883) 'Zu Achilleus und Polyxena', Hermes 18(3): 475-8.

Frangoulidis, S. A. (1992) 'Homeric Allusions to the Cyclopeia in Apuleius" Description of the Robbers" Cave', Parola del Passato 47: 50-8.

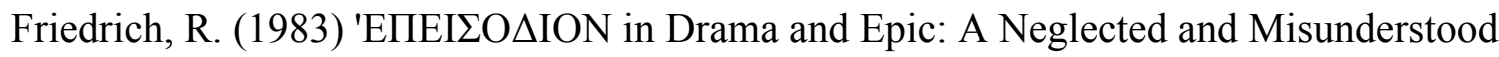
Term of Aristotle's' Poetics", Hermes 111(1): 34-52.

Fusillo, M. (1990) 'Il testo nel testo: la citazione nel romanzo greco', Materiali e discussioni per l"analisi dei testi classici 25: 27-48.

Gallagher, C. (2006) 'The Rise of Fictionality', in The Novel, vol. 2, ed. F. Moretti. Princeton: 336-53.

Haight, E. H. (1947) 'The Tale of Troy: An Early Romantic Approach', The Classical Journal 42(5): 261-9.

Harrison, S. (1990) 'Some Odyssean Scenes in Apuleius' Metamorphoses', Materiali e discussioni per l"analisi dei testi classici 25: 193-201.

-- (ed.) (1999) Oxford Readings in the Roman Novel, Oxford and New York.

--. (2008) 'Intertextuality: The Roman Novel', in The Cambridge Companion to the Greek and Roman Novel, ed. T. Whitmarsh. Cambridge: 227-36.

Hägg, T. (1983) The Novel in Antiquity. Berkeley.

Heath, M. (1989) Unity in Greek Poetics. Oxford.

Holmberg, I. (1998) 'The Creation of the Ancient Greek Epic Cycle', Oral Tradition 13(2): 456-78.

Holzberg, N. (1996) 'The Genre: Novels Proper and the Fringe', in The Novel in the Ancient World, ed. G. Schmeling. Leiden: 11-28.

Huxley, G. L. (1969) Greek Epic Poetry from Eumelos to Panyassis. London.

Klebs, E. (1889) 'Zur Composition von Petronius Satirae', Philologus 47: 623-35.

Konstan, D. (1998) 'The Invention of Fiction', in Ancient Fiction and Early Christian Narrative, eds. R. F. Hock, J. B. Chance \& J. Perkins. Atlanta, GA: 3-17. 
Létoublon, F. (2008) ' $\Lambda$ $\tau o ~ \gamma o v ́ v \alpha \tau \alpha$ : d'Homère aux romans grecs', in Phileuripidès: Mélanges offerts à François Jouan, eds. D. Auger \& J. Peigney. Nanterre: 71123.

Merkle, S. (1989) Die Ephemeris belli Troiani des Diktys von Kreta. Frankfurt am Main. Merkle, S. (1994) 'Telling the True Story of the Trojan War: The Eyewitness Account of Dictys of Crete', in The Search for the Ancient Novel, ed. J. Tatum. Baltimore: 183-96.

Mheallaigh, K. N. (2008) 'Pseudo-documentarism and the limits of ancient fiction', American Journal of Philology 129(3): 403-31.

Milazzo, A. M. (1984) 'Achille e Polissena in Ditti Cretese: un romanzo nel romanzo', Le forme e la storia, Riv. quadrimestr. di studi stor. e lett.(Catania. CUECM) 5: 324.

Morgan, J. (2008) 'Intertextuality: The Greek Novel', in The Cambridge Companion to the Greek and Roman Novel, ed. T. Whitmarsh. Cambridge: 218-27.

--. (2009) 'Petronius and Greek Literature', in Petronius: A Handbook, eds. J. Prag \& I. Repath. Malden, MA: 32-47.

Müller, C. W. (1976) 'Chariton von Aphrodisias und die Theorie des Romans in der Antike', Antike und Abendland 22: 115-36.

Naber, S. A. (1901) 'Ad Charitonem', Mnemosyne 29: 92-9.

Nagy, G. (1990) Pindar's Homer: The Lyric Possession of an Epic Past. Baltimore.

Pavano, A. (1998) 'Le redazioni latine e il presunto originale greco dell'opera di Darete Frigio', Sileno 24(1-2): 207-18.

Perry, B. E. (1967) The Ancient Romances: A Literary-Historical Account of their Origins. Berkeley.

Plazenet, L. (1995) 'Le Nil et son delta dans les romans grecs', Phoenix 49: 5-22.

Repath, I. D. (2005) 'Achilles Tatius' Leucippe and Cleitophon: What Happened Next?', Classical Quarterly 55(1): 250-65.

Richardson, N. J. (1992) 'Aristotle's Reading of Homer and Its Background', in Homer's Ancient Readers: The Hermeneutics of Greek Epic's Earliest Exegetes, eds. R. Lamberton \& J. J. Keaney. Princeton: 30-40.

Robiano, P. (2000) 'La citation poétique dans le roman érotique grec', Revue des études anciennes 102(3/4): 509-29.

Rohde, E. (1914) Der griechische Roman und seiner Vorläufer, 3rd edn. Leipzig.

Scaife, R. (1995) 'The Kypria and Its Early Reception', Classical Antiquity 14(1): 164-92.

Severyns, A. (1928) Le cycle épique dans l'école d'Aristarque. Liège and Paris.

Sullivan, J. P. (1968) The Satyricon of Petronius: A Literary Study. Bloomington.

Swain, S. (ed.) (1999) Oxford Readings in the Greek Novel, Oxford and New York.

Tatum, J. (ed.) (1994) The Search for the Ancient Novel, Baltimore.

Tilg, S. (2010) Chariton of Aphrodisias and the Invention of the Greek Love Novel. New York.

Welcker, F. G. (1849) Der epische Cyclus: oder Die homerischen Dichter, vol. 2. Bonn.

Whitmarsh, T. (2005) 'The Greek Novel: Titles and Genre', American Journal of Philology 126: 587-611.

--. (ed.) (2008) The Cambridge Companion to the Greek and Roman Novel, Cambridge.

--. (2011) Narrative and Identity in the Ancient Greek Novel: Returning Romance. Cambridge. 
${ }^{1}$ See Holzberg 1996. Philostratus' Life of Apollonius of Tyana, which fictionalizes the career of a historical individual, is a good example of a 'fringe' text. The modern study of the novel begins with Rohde's Der griechische Roman und seine Vorlaüfer $\left(1876 ; 3^{\text {rd }}\right.$ ed. 1914). The literature has grown exponentially in the last decades; I can do no more here than direct the reader to a few works providing useful overviews: Hägg 1983, Tatum 1994, Swain 1999, Harrison 1999, Whitmarsh 2008.

${ }^{2}$ I refer to the novels by the titles in most common use in contemporary scholarship. For titling conventions in antiquity, see Whitmarsh 2005. By distinguishing the Greek 'romances' from the Latin 'novels,' I follow the usage of Whitmarsh 2011: 1n1; elsewhere in this essay I apply the term "novel" to the Greek romances as well.

${ }^{3}$ In addition to the passages discussed below, examples include: Chariton's use of the story of Ariadne and Dionysus, which may echo the lost Thebeid(s) (which I include in the Epic Cycle broadly defined); the duel between the brothers Thyamis and Petosiris in Book 7 of Heliodorus' Aethiopica, which evokes Theban legend, and possibly the Thebais; Apuleius' treatment of the 'Judgment of Paris' pantomime in Metamorphoses 10 .

${ }^{4}$ See Sullivan 1968: 186-89. The Vergilian orientation of Eumolpus' poem, which is essentially a rewriting of parts of Aeneid 2 in Senecan iambic trimeters, can be seen particularly clearly in the speaker's markedly Trojan perspective.

${ }^{5}$ Detailed discussion of the dating of Chariton's Chaereas and Callirhoe at Tilg 2010: 36-79 (who also believes that Chariton was the 'inventor' of the Greek romance, and the author of Metiochus and Parthenope as well; his arguments on both points are not, in my view, conclusive). Bowie 2002 makes a well-founded, though sometimes speculative, case for the mid- $1^{\text {st }} \mathrm{c}$. dating of Ninus and Metiochus and Parthenope, arguing also that the next earliest novels might be dated somewhat earlier than has generally been accepted (Xenophon after 65; Antonius Diogenes in the years 98-130; Achilles Tatius before 164). For an overview of the 'current orthodoxy' on the dating of the Greek novels, see Whitmarsh 2011: 261-264.

${ }^{6}$ See Milazzo 1984: 16, Pavano 1998: 211-12.

7 The Greek original for "Dictys" has long been known in papyrus fragments; Merkle 1994: 192 fixes the date of composition between 66 and $200 \mathrm{CE}$. The existence of a Greek original for "Dares" has been a matter of some dispute, but has now been confirmed by the discovery of an ostracon bearing text that corresponds to part of the extant Latin version: see Pavano 1998 and Mheallaigh 2008: 412 (who asserts that the Greek version must have been in circulation in the $2^{\text {nd }} \mathrm{c}$.). The novelistic qualities of these texts are frequently stressed. Mheallaigh, for instance, relates their pseudodocmentary strategies to the Beglaubigungsapparat of Antonius Diogenes; see also Haight 1947, Milazzo 1984. On Philostratus' connection to this tradition, see Merkle 1989: 254-59, 1994: 193-4.

${ }^{8}$ E.g. 1.1.14 (=Il. 21.425, Od. 4.703, etc.), 1.4.6 (=Il. 18.22-24), 2.3.7 ( Od. 17.485, 487), 2.9.6 (= Il. 23.66-67), etc. On Chariton's Homeric quotations, see Müller 1976, Biraud 1985, Létoublon 2008, Morgan 2008: 219n2; on poetic citations in the novels more generally, Fusillo 1990 and Robiano 2000.

${ }^{9}$ Morgan 2008: 220. 
${ }^{10}$ Petronius: Klebs 1889 (who first proposed the analogy between Priapus and Poseidon), Sullivan 1968: 92-8, Harrison 2008: 229, Morgan 2009: 32-8; Apuleius: Frangoulidis 1992, Harrison 1990: 198-200, 2008: 231.

${ }^{11}$ On the tension between 'centrifugal' and 'centripetal' elements in the Greek romances, see Whitmarsh 2011, esp. Ch. 5.

${ }^{12}$ For the importance of plausibility to the concept of fictionality, see Gallagher 2006, esp. p. 339: 'Plausible stories are thus the real test for the progress of fictional sophistication in a culture.'

13 'Episodic' in our sense of the word: Aristotle actually speaks of the praxis polumerēs of these Cyclic poems, while expressing admiration for Homer's incorporation of epeisodia in his more unified epic. On the meaning of epeisodion in this passage, see Friedrich 1983 and Heath 1989: 51-2; on the 'essentially episodic' character of the Cycle, Richardson 1992: 37, as well as Scaife 1995: 170 (on the Cypria) and Holmberg 1998: 459.

${ }^{14}$ See Scaife 1995: 173.

${ }^{15}$ Rohde 1914: 110-11 (102-4 in the $1^{\text {st }}$ ed.); cf. Welcker 1849: 227.

${ }^{16}$ Huxley 1969: 126; Davies 1989: 33.

${ }^{17}$ In Thersites' claim that Achilles harbored a romantic passion for Penthesilea (Arg. 6-8 Bernabé). It is possible that this episode, or some later elaboration on it, also lies in the background of Xenophon's Aigialeus, who has the rather remarkable habit of enjoying an erotic relationship with his wife's embalmed corpse (Eph. 5.1.9). According to the scholia to Sophocles and Lycophron, Thersites claimed that Achilles sought erotic contact with Penthesileia's corpse ( $\Sigma$ ad Soph. Phil. 445 Elmsley; ad Lyc. 999 Scheer). ${ }^{18}$ Later writers make the sacrifice of Polyxena a consequence of Achilles' desire for her, but it is unclear what, if anything, this story owes to the Cycle. Förster 1883: 447 argued that the Cycle knew of Achilles' passion for Polyxena, but later scholarship has tended to see this story as a Hellenistic or later invention (cf. Rohde 1914: 111n3, Merkle 1989: 207).

${ }^{19}$ Severyns 1928: 409; cf. Davies 1989: 94.

20 The Egyptian Menelaus who appears in Achilles Tatius' novel is a playful recasting of this epic prototype. Achilles' Menelaus is a lover just like his epic counterpart, but one with decidedly different tastes: his wanderings away from his Egyptian homeland are the result of an unhappy love affair with a young man (2.34.1-6).

${ }^{21}$ Alluded to at Od. 4.84 and 125-32. On Egypt as a virtually obligatory topos within the novels, and as a metonym for novelistic discourse, see Brioso Sánchez 1992 (esp. p. 204), Plazenet 1995 and Elmer 2008: 429.

${ }^{22}$ See Konstan 1998 on the relationship between referentiality and fictionality: the novels pursue a strategy of auto-referentiality that suspends reference to any external body of facts or knowledge.

${ }^{23}$ From the point of view of the novelists in the $1^{\text {st }} \mathrm{c}$. and later, it is immaterial whether or not the poems of the Cycle were fixed in writing after the Odyssey: the close connection between them is evident in any case. I assume, following Nagy (1990: 72-73), that the Cycle, though textualized at a later date than the Homeric poems, nevertheless represents traditions that evolved alongside those of the Iliad and Odyssey. This assumption, however, has no bearing on my arguments here. 
${ }^{24}$ For a survey of these problems and proposed solutions, see Repath 2005.

${ }^{25}$ First suggested by Naber 1901: 98-99; cf. Perry 1967: 137-9, Connors 2002: 14, 16-17, Tilg 2010: 46. 